WORKING PAPER \#300

INDUSTRIAL RELATIONS SECTION

PRINCETON UNIVERSITY

MARCH 1992

Using Regional Variation in Wages to Measure the Effects of the Federal Minimum Wage

David Card

Princeton University

March, 1992

*I am grateful to D. Christopher Burris for excellent research assistance, and to Charles Brown, Gary Fields, Larry Katz, and Alan Krueger for comments. The computer programs used in this paper are available on request. 


\title{
Using Regional Variation in Wages to Measure the Effects of the Federal Minimum Wage
}

\author{
ABSTRACT
}

The imposition of a national wage standard sets up a useful natural experiment in which the "treatment effect" varies across states depending on the fraction of workers earning less than the new minimum. I use this idea to evaluate the effect of the April 1990 increase in the Federal minimum wage on teenage wages, employment, and school enrollment.

Interstate variation in teenage wages was high at the end of the $1980 \mathrm{~s}$, in part because 16 states had enacted state-specific minimums above the prevailing Federal rate. Comparisons of grouped and individual state data confirm that the rise in the minimum wage significantly increased teenage wages. There is no evidence of corresponding losses in teenage employment, or changes in teenage school enrollment.

David Card

Department of Economics

Princeton University

Princeton NJ 08544 
One of the traditional criticisms of a federal minimum wage policy is that it imposes a higher relative wage floor in regions with lower average wages (see Stigler (1946) pp. 360-361). An appropriate minimum wage for New Jersey, for example, may have devastating labor market consequences in Mississippi. 1 From an evaluation perspective, however, a uniform minimum wage is an under-appreciated asset. A rise in the Federal minimum wage will typically affect a larger fraction of workers in some states than others. This variation provides a simple natural experiment for measuring the effect of legislated wage floors, with a "treatment effect" that varies across states depending on the fraction of workers initially earning less than the new minimum.

This paper uses the experiences following the April 1990 rise in the Federal minimum wage to evaluate the effects of minimum wages on the teenage labor market. In 1989 one-quarter of a11 16-19 year olds earned between $\$ 3.35$ per hour (the existing Federal minimum rate) and $\$ 3.80$ per hour (the new minimum). Across states, however, this fraction varied from under 10 percent in New England and California to over 50 percent in many Southern states. Much of this variation is attributable to the presence of state-specific wage floors above the Federal rate. In the late 1980s many states responded to the decade-long freeze in the Federal minimum wage by raising their own minimum rates above $\$ 3.35$ per hour. These statespecific wage floors created remarkable geographic dispersion in teenage wage rates, setting the stage for the empirical analysis here.

Simple models of the teenage labor market predict varying responses to the rise in the Federal minimum wage, depending on the fraction of workers

${ }^{1}$ A classic example of this reasoning is the effect of the Federal minimum wage in Puerto Rico -- see Reynolds (1965). 
initially earning beiow the new rate (see Welch (1976) for a thorough overview). Examination of the interstate patterns of wage and employment growth for teenagers between 1989 and 1990 provides a credible test that changes in teenage labor market outcomes reflect changes in the minimum wage, rather than other factors that coincided with the law. A similar evaluation methodology figured prominently in many early studies of minimum wage laws (see especially Lester (1965, pp. 518-523)), but has been largely supplanted in the recent literature by aggregate time-series studies (for example, Welch (1976), Brown, Gilroy and Kohen (1982, 1983), Wellington (1991)).

The empirical results confirm that increases in the Federal minimum wage raise teenage wage rates. For example, between 1989 and 1990 average teenage wages rose 6 percent faster in a group of low-wage states (where over 40 percent of teenagers earned $\$ 3.35-3.79$ per hour in 1989) than in a group of high-wage states (where less than 10 percent of teenagers earned $\$ 3.35-3.79$ per hour in 1989). Surprisingly, there is no evidence that the rise in teenage wages resulted in any loss in teenage employment, or any change in teenage school enrollment.

\section{Minimum Wage Statutes in 1989-90}

The federal minimum wage increased to $\$ 3.35$ per hour in January 1981 and remained frozen throughout the 1980s. By the close of the decade cumulative inflation had eroded the purchasing power of the minimum wage to its lowest level since January $1950 .^{2}$ The decline in the real value of the

${ }^{2}$ Using the Consumer Price Index for all items, the real Federal minimum in January 1950 was $\$ 4.08$ (in 1990 dollars). It fluctuated between $\$ 3.64$ (in 1954) and $\$ 6.00$ (in 1968). Its value in 1989 was $\$ 3.53$. 
Federal minimum prompted state legislatures and wage boards to respond with state-specific minimum rates above the Federal standard. The first of these higher minimums arose in the New England states - - Maine $(\$ 3.45$ effective January 1985), Massachusetts and Rhode Island (both $\$ 3.55$ effective July 1986), New Hampshire (\$3.45 effective January 1987) and Connecticut ( $\$ 3.75$ effective October 1987). By 1989 a total of 16 states and the District of Columbia had wage floors above $\$ 3.35 .^{3}$ The Appendix presents a list of the various state laws as of January 11990.

Political pressure for an increase in the Federal minimum wage culminated in March 1989 with passage of a House resolution to raise the minimum to $\$ 4.55$ over three years. A similar bill passed the Senate but was vetoed by the President. A bill providing for smaller wage increases and a liberalized youth subminimum was introduced in November 1989 and passed into law with Presidential support. This bill raised the minimum wage in two steps --to $\$ 3.80$ on April 11990 and to $\$ 4.25$ on April 11991 - and set a training minimum equal to 85 percent of the regular minimum wage for employees aged 16-19.

Other provisions of the Federal minimum wage were modified only slightly by the April 1990 law. The tip credit, which allows employees to credit a portion of their tips toward the minimum, was raised from 40 to 45 percent. Consequently, the Federal minimum wage for tipped employees rose from $\$ 2.01$ to $\$ 2.09$ per hour. Exemptions for smaller businesses were also expanded and simplified. Previously, retail and service enterprises with an

3 The widespread setting of state minimum wages above the Federal rate was unprecedented. For example, Cullen (1960) observed that the federal minimum wage had served as a ceiling for state-specific minimum rates during the period from 1940 to 1960 . 
annual sales volume of less than $\$ 250,000$ were exempt from coverage. This threshold was raised to $\$ 500,000$ and extended to all industries. ${ }^{4}$

\section{The Effect On Teenagers}

a. Overview

Because teenagers are typically at the bottom of the earnings distribution, and because a large fraction of low-paid workers are teenagers, the minimum wage literature has concentrated on the youth labor market (see the report of the Minimum Wage Study Commission (1981) and the article by Brown, Gilroy and Kohen (1982)). Table 1 presents some descriptive information on teenagers taken from the monthly files of the Current Population Survey (CPS) in 1989 and 1990. Each month, individuals in the two "outgoing rotation groups" of the survey are asked to provide supplementary information on earnings and hours on their main job (if they have one). The data in Table 1 and throughout this paper are based on the responses for this $1 / 4$ sample of the CPS. To facilitate a comparison of the periods before and after the rise in the minimum wage, the samples include only the April-December surveys of each year.

The first and sixth columns of Table 1 present data for all teenagers while the remaining columns pertain to employed teenagers and those with hourly wages in specified intervals. ${ }^{5}$ The teenage population of the U.S. includes a high fraction of nonwhites (20\%) and Hispanics (10\%): the respective proportions of the working population are lower. Employed teenagers also tend to be older and have more years of completed education

${ }^{4}$ See Bureau of National Affairs (undated) $91: 1415-1422$.

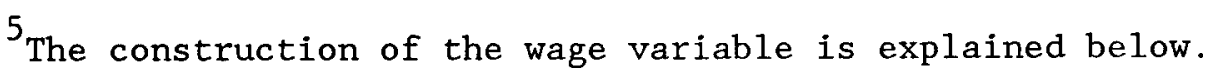


than nonworkers. A majority of teenagers (56.5\%) report that they are "attending or enrolled in high school, college, or university". A slightly lower fraction (48\%) report that their main activity during the survey week was "in school". These fractions must be interpreted carefully, since school attendence rates vary over the year. During 1989 the average fraction of teenagers enrolled in school varied from 77 percent in April to 14 percent in July and August.

The CPS collects hourly wage information for individuals who are paid by the hour ( 938 of teenagers) and usual weekly earnings for other workers. The wage measure presented in row 10 of Table 1 (and used to define the columns of the table) represents the reported wage for hourly-rated workers and the ratio of usual weekly earnings to usual weekly hours for other workers. By this "straight-time" wage measure, teenage workers earned an average of $\$ 4.61$ per hour in 1989 , compared to an average of $\$ 10.10$ for al1 workers in the US. Seven percent of teenagers earned less than the Federal minimum wage of $\$ 3.35$ per hour, 248 earned from $\$ 3.35$ to $\$ 4.24$ per hour, and 648 earned $\$ 3.80$ per hour or more. Another 58 were either selfemployed, worked without pay, or failed to report earnings information. 6

One difficulty with the wage measure in row 10 is that some workers who report being paid by the hour also receive tips or commissions. This practice is especially widespread in retail trade, where over one-half of teenagers are employed (see row 15 of the table). For hourly-rated workers the CPS also collects usual weekly earnings including regular tips and

${ }^{6}$ The Census Bureau a1locates responses for individuals who do not answer the earnings questions in the CPS (about 3 percent of teenage workers). To avoid measurement error, I do not use the earnings data for these individuals. 
commissions. This information can be used to construct an estimate of

average weekly tips and an alternative measure of hourly wages. The

average level of wages including pro-rated tips (in row 11 of Table 1) is 3 percent higher than the average based on straight-time earnings, reflecting the addition of tips and commissions for just over 10 percent of teenage workers. 7

The characteristics of teenagers with "straight-time" earnings less than the minimum wage are presented in the third column of Table 1 . There are a variety of explanations for subminimum pay, including non-coverage (for tipped employees in retail trade and full-time students under the student subminimum ${ }^{8}$ ), employer non-compliance, and measurement error. Examination of the wage distribution of teenagers earning less than $\$ 3.35$ shows a substantial spike (218 of workers) near the tipped minimum of $\$ 2.01$ per hour, suggesting that many subminimum workers are exempt from the $\$ 3.35$ standard. This is further confirmed by the higher incidence of tip income among subminimum-wage teens: 258 of subminimum wage earners report strictly positive tip income, versus 118 overall. When hourly wages are calculated including tip income, 19 percent of workers with straight-time pay less than $\$ 3.35$ have effective wages above the minimum wage. Even including

7 To avoid problems posed by measurement error, I set the wage including tips equal to the reported straight-time hourly wage unless the difference between average weekly earnings including tips and the product of the straight-time wage and usual weekly hours is positive. The average wage measures in Table 1 also exclude individuals with reported or imputed wages less than $\$ 1$ or greater than $\$ 20$ per hour.

${ }^{8}$ Under the pre-1989 law, employers in retail trade, agriculture, and higher education were permitted to pay full-time students a subminimum $15 \%$ below the regular rate. The available evidence suggests that usage of this exemption was relatively modest. Freeman, Gray, and Ichniowski (1981) estimate that only 3 percent of student hours in the late 1970s (when the minimum was relatively high) were worked under the subminimum provisions. 
usual tip income, however, a substantial number of teenagers reported subminimum wages in 1989 .

Employer non-compliance may explain some of this. Compared with other teenagers, subminimum workers are more likely to work in agriculture and household services, where non-compliance may be higher. Another factor is the relatively high fraction of subminimum wage workers who report being paid by the week or month, rather than by the hour (25 percent versus 7 percent of teenagers as a whole). Some salaried workers are legally exempt from the minimum wage, while others may have over-reported their usual weekly hours, leading to a downward bias in their imputed hourly wage.

The next column of Table 1 presents the characteristics of teenagers reporting hourly wages of $\$ 3.35$ to $\$ 3.79$ in 1989 . For simplicity I refer to these as "affected workers", since a rise in the minimum wage is most likely to affect employees of complying firms in the covered sector who previously earned less than the new rate. Affected teenagers are more likely to be enrolled in school than those with either higher or lower wages, and they are also more likely to be employed in retail trade. Some 40 percent of affected workers report an hourly wage exactly equal to the 1989 minimum wage. Their wage distribution shows additional spikes at $\$ 3.50$ and $\$ 3.75$, with an average of $\$ 3.49$ per hour.

The five right-hand columns of Table 1 present corresponding information for 1990. Teenagers as a whole reported a slight increase in school enrollment rates from the last 3 quarters of 1989 to the last three quarters of 1990. The teenage employment rate, on the other hand, fell by 
2.5 percentage points. ${ }^{9}$ For comparison, the annual average teenage employment rates for 1989 and 1990 (published by the Bureau of Labor Statistics) were 47.58 and 45.48. Thus, the employment data for April to December reflect a slightly larger downturn than the annual averages.

The teenage wage distribution also shifted between 1989 and 1990, with a sharp reduction in the fraction of workers earning $\$ 3.35-\$ 3.79$ per hour (from 24.48 to 7.48 ) and a mean increase of 58. A comparison of the 1989 and 1990 distributions shows the elimination of the previous spike at $\$ 3.35$ per hour and the emergence of a new spike at $\$ 3.80$. Interestingly, there was only a slight reduction in the fraction of teens reporting wages (exclusive of tips) under $\$ 3.35$.

While these patterns are suggestive of the effect of the new minimum wage law, even stronger evidence of its impact is provided in Figure 1 , which shows quarterly averages of the fractions of teenagers earning less than $\$ 3.35$, exactly $\$ 3.35$, and $\$ 3.36-\$ 3.79$ per hour from $1989-$ I to $1990-I V$. The figure indicates an abrupt drop in the fraction earning less than $\$ 3.80$ per hour in the second quarter of 1990 (i.e, after April 1). Most of this drop reflects a reduction in the fraction earning $\$ 3.35-\$ 3.79$, with little evidence of an effect on the fraction earning less than $\$ 3.35$. The effect of the minimum wage law was mainly concentrated on workers who previously earned at least the old minimum wage but less than the new rate.

Two other aspect of Figure 1 also deserve comment. First, there is only a slight dip in the fraction earning less than $\$ 3.80$ per hour in the first quarter of 1990 , even though the new minimum wage was signed into law in

${ }^{9}$ The standard errors of the 1989 and 1990 employment rates for all teenagers in the top row of Table 1 are both 0.48 . The standard error for the change in employment rates between 1989 and 1990 is $0.5 \%$. 
November 1989. Most employers evidently waited until the effective date of the law to increase the wages of their teenage employees. Second, the fraction of workers earning exactly $\$ 3.35$ shows a continuing decline after 1990-II, suggesting some lag in the adjustment of wages (or in the reporting process).

Before turning to a regional analysis of the effects of the increased Federal minimum wage, is worthwhile analyzing the aggregate change in teenage employment between 1989 and 1990. Much of the existing literature has used the correlation between minimum wages and aggregate teenage employment to infer the effect of the law. As noted in Table 1, teenage employment fell from 1989 to 1990. Part of this decline is clearly attributable to the 1990 recession, which began in midyear. The youth labor market is highly cyclical, and the onset of a recession would be expected to lower teenage employment by several percentage points. This historical relationship is illustrated in Figure 2, which graphs annual average teenage employment rates for 1975-1990 along with the predicted rates from a linear regression on a trend and the overall employmentpopulation ratio. ${ }^{10}$ The prediction equation tracks the actual teenage employment rate up to 1989 remarkably we11, and indicates that the 1990 rate was about 0.6 percent lower than expected. While it may be tempting to attribute this discrepancy to the effect of the increased minimum wage, it should be noted that the real minimum wage was relatively high in 1976 ,

${ }^{10}$ The regression is estimated with data for 1975-89. The fitted equation is:

Teen Employment $=$ Constant $-0.86 *$ Trend $+2.17 *$ Overall Employment Rate with an R-squared of 0.99 . 
1979, and 1981, and then trended down throughout the late 1980s with 1ittle apparent effect on employment. ${ }^{11}$

\section{a. A Grouped Analysis}

The nationwide data in Table 1 and Figure 1 conceal considerable interstate variation in the distribution of teenage wages prior to the rise in the Federal minimum wage. This wide variation suggests two complementary approaches to analyzing the effect of the 1990 increase in the minimum wage. The first is to aggregate states into groups with similar fractions of affected workers in 1989. This approach generates relatively large sample sizes in each group, permitting a quarterly analysis along the lines of Figure 1. A second approach is to use all 51 states and pool the months before and after April 1990 for each state. I first present the grouped analysis, then turn to a state-by-state analysis.

Figure 3 plots the fraction of workers earning $\$ 3.35-\$ 3.79$ by quarter for 3 groups of states: states with under 208 of teenage workers earning $\$ 3.35-\$ 3.79$ in 1989 ("high-wage states"); states with over 40 percent of teenage workers earning $\$ 3.35-\$ 3.79$ in 1989 ("low-wage states"); and a11 other states ("medium-wage states"). The high wage group contains 12 states, most of which had passed state-specific minimum wages above $\$ 3.35$ per hour (all of New England, New York, New Jersey, Minnesota, Delaware, Maryland, District of Columbia, Nevada, Washington, California, Alaska, and

11 If the prediction equation is re-estimated including the logarithm of the real value of the Federal minimum wage (deflated by the Consumer Price Index), the estimated minimum wage coefficient is -2.5 , with a standard error of 1.7. This coefficient implies that a 10 percent increase in the minimum wage will reduce teenage employment by 0.25 percent - - a smaller effect than is usually estimated in the literature. See Wellington (1991) for some recent estimates. 
Hawaii). The low wage group contains 13 Southern and Mountain states plus the Dakotas (West Virginia, South Carolina, Kentucky, Tennessee,

Mississippi, Arkansas, Louisiana, Oklahoma, Montana, Wyoming, New Mexico, North Dakota, and South Dakota). The medium wage group includes the remaining 26 states. As expected, the impact of the 1990 minimum wage law is concentrated among the low and medium wage states. Both state groups show a sharp decline in the fraction of teenagers earning $\$ 3.35-\$ 3.79$ per hour after April 1 1990. By the end of 1990, the fractions of teenagers earning $\$ 3.35$ to $\$ 3.79$ per hour were remarkably similar in all three sets of states.

Table 2 presents quarterly averages of teenage wages and employment rates by state group, along with their sampling errors and the differences in the outcomes between corresponding quarters of 1989 and 1990. Assuming that underlying labor market trends were the same in the three group of states, one way to estimate the effect of the Federal minimum wage is to compare outcomes in 1990 to outcomes for the same quarter in 1989, and then to compare these differences across the three groups of states. To facilitate this comparison the bottom row of the table gives the average differences by state group between the second, third, and fourth quarters of 1989 and 1990 .

Looking first at earnings, the high wage states show an average 48 wage gain between 1989 and 1990, with no evidence of an accelerated trend after 1990-I (i.e., after the increase in the minimum wage). Average wages in the low and medium wage states, on the other hand, show a noticeable upsurge in 1990-II. Comparing the last 3 quarters of 1989 and 1990 across the 3 groups, the data in Table 2 suggest that the rise in the Federal 
minimum wage increased average teenage wages by 28 in the medium wage states, and by 68 in the low-wage states.

As a benchmark it is useful to compare these estimated impacts to the wage gains implied by a naive model in which the only effect of the minimum wage is to raise the earnings of affected workers up to the new minimum. Such a model will tend to understate the wage gains if there are significant disemployment effects of the rise in the minimum wage, or if the increase in the minimum wage "spills-over" to higher wage workers. 12 In low-wage states the fraction of affected workers fell from over 508 in 1989 to 108 in 1990-IV. Ignoring any disemployment or spillover effects, the predicted effect of the increased Federal minimum on average wages in the low-wage states is then 0.40 times the average percentage increase for a wage earner who moves from the affected wage range to the new minimum wage. From Table 1, the average wage of affected workers was $\$ 3.49$ per hour. An increase to $\$ 3.80$ is therefore equivalent to a 98 wage increase. Thus, if the only effect of the minimum wage is to increase the earnings of workers in the $\$ 3.35-3.79$ range up to $\$ 3.80$, the predicted wage impact in the low wage states is 3.68 . A similar calculation for the medium wage states implies a $2.1 \%$ wage impact. These benchmarks provide a close approximation to the observed wage effect in the medium-wage states but significantly under-predict the wage increases in low-wage states.

The right-hand columns of Table 2 present teenage employment-population rates by state group and quarter. One obvious aspect of these data is the seasonal pattern of employment, which shows a peak in the third quarter and a trough in the first. It is also interesting to note that teenage

${ }^{12}$ See Grossman (1983) for an earlier analysis of this spillover hypothesis. 
employment increased in all three groups of states between 1990-I and 1990II, although employment rates were uniformly lower in 1990 than 1989 . The quarterly differences in the lower panel indicate that teenage employment fell by more in the high-wage states than in the low wage states. Averaged over the last three quarters of each year, teenage employment growth was 1.58 higher in the low wage states than the high-wage states (standard error $=1.5 \%$, with no difference between the medium-wage and high-wage states.

Ignoring other sources of relative teenage employment growth, the data in Table 2 suggest that the rise in the federal minimum wage increased teenage employment in the low-wage states, with no measurable effect in the medium wage states. The effect in low-wage states is the opposite of the prediction from conventional models of the teenage labor market. One explanation for this finding is inter-state variation in the timing and severity of the 1990 downturn. In fact there is some evidence of a stronger downturn in the initially high-wage states and a more moderate recession in the low-wage states. Between the last 3 quarters of 1989 and 1990 the employment-population ratio for all workers grew by 0.45 percentage points in the low-wage states, by -0.01 points in the mediumwage states, and by -0.23 points in the high-wage states. These differences can potentially explain at least some of the differences in teenage employment growth between the 3 state groups.

To investigate this more formally I fit a regression model to the quarterly teenage employment rates of the 3 state groups, including groupspecific intercepts, quarterly dummies, the overall employment rate for the state-group and quarter, and group-specific dummies measuring the change in 
teenage employment after 1990-II (i.e., after the increase in the minimum wage). ${ }^{13}$ The estimated employment effects in the post-increase period are -2.58 for the low-wage states, $-2.7 \%$ for the medium-wage states, and -2.68 for the high-wage states. These estimates suggest that differences in the strength of the aggregate labor market can potentially explain all of the inter-group variation in teenage employment growth between the last three quarters of 1989 and 1990. Accounting for these aggregate factors, however, there is no indication of an adverse employment effect in the lowwage states, where the increase in the Federal minimum wage raised teenage wages by 68 .

\section{a. An Analysis by State}

An alternative to the grouping strategy used in Table 2 and Figure 3 is to treat each state as a separate observation, and to correlate changes in employment, wages, and other outcomes with the fraction of affected workers in the state. Owing to the relatively small numbers of observations for many states, I have not analyzed quarterly data by state. Rather, I have aggregated data for the last three quarters of 1989 and 1990 for each state. Comparisons between 1989 and 1990 allow a "pre/post" comparison of the effect of the increase in the Federal minimum on April 1 1990. The data for the two years are drawn from the same months and therefore abstract from any systematic seasonal effects.

Table 3 summarizes teenage labor market data by state for 1989 and 1990. The first column of the table presents the fraction of teenagers

${ }^{13}$ The model is estimated on data for 1989 and 1990. The implied elasticity of the teenage employment rate with respect to the overall employment rate is 1.70 (with a standard error of 0.83 ). 
earning $\$ 3.35-\$ 3.79$ per hour in the last 3 quarters of 1989 . As noted earlier, this fraction varies widely, from 0 in Alaska to 54.4 percent in West Virginia. Other columns of the table report average teenage wage rates, average teenage employment-population rates, and the changes in the mean $\log$ wage rate and the employment-population rate in each state. The right-hand column of the table gives the average number of teenagers in the CPS sample for the state (for April-December of 1989 and 1990). For many states the sample is sma1l, leading to relatively large sampling errors in the estimated changes in wages and employment rates. 14

Figure 4 illustrates the interstate correlation between the fraction of teenagers earning $\$ 3.35-\$ 3.79$ per hour in 1989 and the increase in mean $\log$ wages between 1989 and 1990. The estimated regression model corresponding to the figure is presented in the first column of Table $4 .^{15}$ The estimated slope is 0.15 , somewhat higher than the benchmark effect (.088) predicted by assuming that the rise in the minimum wage simply raised the wages of those in the affected wage range to $\$ 3.80$ per hour. As suggested by the figure, the regression coefficient is relatively precisely estimated: variation in the fraction of affected workers in 1989 explains a respectable 30 percent of the interstate variation in wage growth between 1989 and 1990.

${ }^{14}$ The CPS sample design implies that $1 / 2$ of individuals in the 1989 sample appear in the 1990 sample. I have adjusted the sampling errors in Table 3 to account for this fact, assuming that the correlation of individual-specific employment and wage outcomes across the 2 years is 0.75 .

${ }^{15}$ I have weighted the regression model by the average CPS extract size for each state. Unweighted results are very similar. 
Columns (2) and (3) of Table 4 introduce two alternative "macro-level" labor market indicators into the wage change equation. These are the change in the overall employment-population rate in the state between 1989 and 1990, and the corresponding change in the overall unemployment rate. Both variables are based on state-level averages published in the Bureau of Labor Statistics" "Geographic Profiles of Employment and Unemployment". Changes in overall employment or unemployment rates help to control for any state-specific labor demand shocks that may be correlated with the fraction of affected workers. As it happens, neither of these variables is very highly correlated with the growth rate of teenage wages, and their inclusion hardly effects the model.

Figure 5 plots state-level observations on the change in the teenage employment population rate between 1989 and 1990 against the fraction of affected wage earners in 1989. Unlike the corresponding plot for wage changes, this figure suggests no strong relation between the fraction of affected wage earners and the change in employment rates. The estimated regression models in columns 4-6 of Table 4 confirm this visual impression. Whether or not overall labor market indicators are included as additional controls, there is virtually no effect of the fraction of affected teenagers in 1989 on the change in employment rates. ${ }^{16}$

${ }^{16}$ One potential issue in the estimation of standard errors for the models in Table 4 is the presence of systematic correlation between the residuals of nearby states. This "spatial correlation" will tend to lead to understated standard errors. As a rough check, I computed the DurbinWatson (DW) statistics for the residuals. If the states are sorted by region, this provides a test for spatial correlation. The DW statistics for both the wage and employment models are very close to 2 , giving no evidence of spatial correlation. 
The estimated wage change models in columns $1-3$ and the estimated employment change models in columns 4-6 can be interpreted as "reducedform" equations from a very simple structural model which explains the wage increase between 1989 and 1990 in state $i\left(\Delta W_{i}\right)$ as a function of the fraction of teenagers in the affected wage range in the state in 1989 $\left(\right.$ F89 $\left.{ }_{i}\right)$ and other variables $\left(\mathrm{X}_{i}\right)$, and the employment change in state $i\left(\Delta \mathrm{E}_{i}\right)$ as a movement along the teenage employment demand function:

(1) $\Delta \mathrm{W}_{\mathrm{i}}=\mathrm{a}+\mathrm{b} \mathrm{F} 89_{\mathrm{i}}+\mathrm{c} \mathrm{X}_{\mathrm{i}}+\mathrm{e}_{\mathrm{i}}$

(2) $\Delta \mathrm{E}_{i}=\alpha+\beta \Delta \mathrm{W}_{i}+\gamma \mathrm{X}_{i}+\varepsilon_{i}$.

Here the coefficient $\beta$ is a conventional labor demand elasticity, and $e_{i}$ and $\varepsilon_{i}$ are residual components of wage growth and employment demand. The reduced-form employment change equation is

(3) $\Delta \mathrm{E}_{\mathrm{i}}=\alpha+\mathrm{b} \beta \mathrm{F} 89_{i}+(\gamma+c \beta) \mathrm{x}_{i}+\beta \mathrm{e}_{i}+\varepsilon_{i}$. Comparison of (1) and (3) shows that the elasticity of demand for teenage labor can be obtained by taking the ratio of the "Fraction Affected" coefficient in the employment growth equation to the corresponding coefficient in the wage growth equation. Alternatively, the same numerical estimate of the demand elasticity can be recovered by estimating the employment change equation (2) by two-stage least squares, using the fraction of teenagers in the affected wage range as an instrumental variable for the change in teenage wages. Such estimates are presented in columns 7-9 of Table 4 .

The implied employment demand elasticities are uniformly small. When the overall employment-population ratio is included as a control variable (column 8 ) the estimated elasticity is negative but close to 0 . Without controlling for overall labor market conditions (column 7) or using the 
overall unemployment rate as a control (column 9) the estimated elasticity is positive but close to 0 . As suggested by the grouped analys is in Table 2 , there is no evidence of a significant disemployment effect of the Federal minimum wage.

The analysis in Table 4 can be extended in several directions. One extension is to model the dynamic structure of employment changes. Another is to consider more general measures of the impact of the Federal minimum wage on state-specific wage changes. Both issues are addressed by the estimates in Table 5. The first 4 columns of this table report reducedform employment growth regressions that include lagged values of the dependent variable. ${ }^{17}$ For simplicity, I have only reported models that include the overall employment-population ratio -- models that include the aggregate unemployment rate as an alternative control variable yield similar conclusions. The estimates in column 1 suggest that the lagged employment growth exerts a significant negative effect on current growth. This pattern is consistent with an underlying second-order autoregressive model of teenage employment at the state level. ${ }^{18}$ In column 2 I include the lagged value of the overall employment change. Controlling for the contemporaneous aggregate employment change and the lagged dependent variable, this variable has a small and statistically insignificant coefficient. In either specification the coefficient of the fraction of

${ }^{17}$ The dependent variable in Table 5 is the state-specific change in the teenage employment rate between the last 3 quarters of 1989 and the last 3 quarters of 1990. The lagged change in the teenage employment population ratio is based on data for all 4 quarters of 1988 and 1989.

${ }^{18}$ A similar pattern for overall state-level employment is suggested by the results in Topel (1986). 
affected teenager wage earners (in row 1) is small and insignificantly different from 0 .

One potential difficulty with the estimated models in columns 1 and 2 is the presence of measurement error in the lagged dependent variable.

Random sampling errors in the state-specific teenage employment rate will tend to create a negative bias in the estimated coefficient of the lagged teenage employment rate. To check for the magnitude of this bias, column 3 presents a model in which the lagged dependent variable is instrumented by the lagged change in the overall employment-population rate. The results of this exercise suggest the bias is small enough to be safely ignored.

Although labor demand shocks affecting teenage employment in a state are likely to be captured by the overall employment rate in the state, it is possible that other regional shocks may also play a role. To test this hypothesis column 4 of Table 5 presents a model that includes the regional change in the overall employment rate (for 9 different regions of the country). The addition of this variable lowers the coefficient on the state-specific employment rate, although the regional employment change is not itself statistically significant. The coefficient of the fraction of affected wage earners also falls slightly (to -0.003).

Columns 5-9 of Table 5 present instrumental variables estimates of the state-specific teenage employment demand equation, allowing for an effect of the lagged dependent variable. These models differ by the choice of variable(s) used as instruments for the change in teenage wages. Following the specifications of Table 4 , columns 5 and 6 present models that use the fraction of teenagers earning \$3.35-3.79 per hour in 1989 to instrument the wage change. In columns 7-9 I use three alternative measures of the wage 
impact of the Federal minimum. The model in column 7 uses the fraction of teenagers earning exactly $\$ 3.35$ per hour in 1989 . The model in column 8 uses both the fraction of teenagers at the old minimum wage and the fraction in the affected wage range. Finally, the model in column 9 uses the fractions of teenagers earning less than $\$ 3.35$ and the fraction earning $\$ 3.35-3.79$ per hour in 1989. Regardless of specification the models suggest negligible wage elasticities, although the estimated standard errors are relatively large and one cannot reject the hypothesis of a small negative employment demand elasticity.

The results in Tables 4 and 5 suggest that interstate differences in teenage employment growth between 1989 and 1990 were unrelated to the state-specific wage impact of the Federal minimum wage increase. Another closely monitored outcome for teenagers is the fraction enrolled in school. A standard hypothesis in the literature (see for example Ehrenberg and Marcus (1980)) is that increases in the minimum wage will increase school enrollment. This prediction, however, is based on the assumption that increases in the minimum wage reduce teenage employment opportunities. In light of the results in Tables 4 and 5 , it is interesting to correlate interstate changes in enrollment with differences in the wage effect of the Federal minimum wage.

To abstract from the seasonal pattern of school enrollment I used CPS data for September-December of 1989 and 1990 to construct state-specific estimates of the change in the fraction of teenagers enrolled in school (either full or part-time). In the U.S. as a whole the fraction of teenagers enrolled in school during September-December rose from $73.7 \%$ in 1989 to $74.6 \%$ in 1990 . Across states changes in enrollment are negatively 
correlated with changes in employment rates (the correlation is -0.19 , with a probability value of 0.18 ). I then fit a simple regression model for the change in enrollment as a function of the change in the overall employment rate in the state and the fraction of teens in the affected wage range in 1989. The coefficient of the overall employment change variable is -0.46 (with a standard error of 0.77 ) suggesting that enrollment growth was faster (although not significantly so) in states that experienced bigger employment reductions between 1989 and 1990. The coefficient of the fraction affected variable is -0.003 (with a standard error of 0.05 ) implying that changes in enrollment were essentially unrelated to the potential wage impact of the the rise in the Federal minimum wage. As with the employment results, there is no evidence of a connection between teenage school enrollment and the minimum wage.

\section{v. Conclusions}

This paper uses the experiences generated by the April 1990 rise in the Federal minimum wage to measure the effects of the minimum wage on teenage workers. The imposition of a national wage standard sets up a very useful natural experiment in which the "treatment effect" in any particular state depends on the fraction of workers initially earning less than the new minimum. By the end of the 1980s interstate dispersion in teenage wages was remarkable. Many states had already passed state-specific minimum wages above the new Federal standard. The fraction of teenagers potentially affected by the rise in the minimum wage ranged from under 5 percent in some New England and West-coast states to over 50 percent in some Southern states. 
The 1990 law raised the minimum wage by 13 percent. Estimates in the previous literature suggest that this increase would lower aggregate teenage employment by 1 to 4 percentage points (see Brown, Gilroy, and Kohen (1982)). More importantly, however, these employment losses should have been concentrated in low-wage states, providing a test that the changes are attributable to the minimum wage.

Comparisons of grouped and individual state data confirm that the rise in the minimum wage raised average teenage wages. The wage gains were as big or slightly bigger than the increases predicted by assuming that individuals earning less than the new minimum rate had their wages "topped up" to the new standard. On the other hand, there is no evidence that the rise in the minimum wage significantly lowered teenage employment rates or altered school enrollment patterns. These findings, although at odds with conventional predictions, are consistent with the earlier "case study" literature (Lester (1960)) and with the findings of two recent studies using a similar methodology: my (Card (1991)) study of the 1988 California minimum wage law; and Katz and Krueger's (1992) study of the effects of the recent Federal minimum wage increases on the fast food industry in Texas. 


\section{References}

Brown, Charles, Curtis Gilroy and Andrew Kohen. "The Effect of the Minimum Wage on Employment and Unemployment". Journal of Economic Literature 20 (June 1982): 487-528.

on the Effect of the Minimum Wage on Youth Employment and Unemployment". Journal of Human Resources 18 (Winter 1983): 3-31.

Bureau of National Affairs. Labor Relations Reporter Wages and Hours Manual. Washington DC: Bureau of National Affairs, undated.

Card, David. "Do Minimum Wages Reduce Employment? A Case Study of California, 1987-89". National Bureau of Economic Research Working Paper 3710, May 1991.

Cullen, Donald E. Minimum Wage Laws. Bulletin 43 New York State School of Industrial and Labor Relations. Ithaca New York: February 1961.

Ehrenberg, Ronald and Alan J. Marcus. "Minimum Wage Legislation and the Educational Outcomes of Youth". In Ronald Ehrenberg, editor, Research in Labor Economics Volume 3. Greenwich Connecticut: JAI Press, 1980.

Freeman, Richard, Wayne Gray and Casey Ichniowski. "Low Cost Student Labor: The Use and Effects of the Youth Subminimum Provisions for Full-Time Students". In Volume $V$ of Report of the Minimum Wage Study Commission. Washington: USGPO, 1981.

Grossman, Jean B. "The Impact of the Minimum Wage on Other Wages". Journal of Human Resources 18 (Summer 1983): 359-378.

Katz, Lawrence and Alan Krueger. "The Effects of the Minimum Wage on the Fast Food Industry". Unpublished Manuscript, Princeton University, February 1992.

Lester, Richard A. "Employment Effects of Minimum Wages". Industrial and Labor Relations Review 13 (january 1960): 254-264. Macmillan, 1964.

Minimum Wage Study Commission. Report of the Minimum Wage Study Commission Washington: USGPO, 1981.

Reynolds, Lloyd G. "Wages and Employment in the Labor Surplus Economy". American Economic Review 55 (March 1965): 19-39.

Stigler, George. "The Economics of Minimum Wage Legislation". American Economic Review 36 (June 1946): 358-365. 
Topel, Robert H. "Local Labor Markets". Journal of Political Economy 94 (Supplement, June 1986): S111-S143.

United States Department of Labor Bureau of Labor Statistics. "Geographic Profiles of Employment and Unemployment". Bulletin Numbers 2327 (1988 edition), 2361 (1989 edition) and 2381 (1990 edition). Washington DC: USGPO, various years.

Welch, Finis. "Minimum Wage Legislation in the United States". In Orley Ashenfelter and James Blum, Editors. Evaluating the Labor Market Effects of Social Programs. Princeton New Jersey: Princeton University Industrial Relations Section, 1976.

Wellington, Alison J. "Effects of the Minimum Wage on the Employment Status of Youths: An Update". Journal of Human Resources 26 (Winter 1991): $27-46$. 
Appendix Table State Minimum Wage Laws in 1989-90

\begin{tabular}{|c|c|c|c|}
\hline State & Minimum Rate & $\begin{array}{l}\text { Effective } \\
\text { Date }\end{array}$ & Comments \\
\hline \multicolumn{4}{|c|}{ Over $\$ 3.80$ as of January 1989: } \\
\hline Alaska & $\$ 3.85$ & Jan. 1981 & $\begin{array}{l}\text { state sets minimum } \\
0.50 / \mathrm{hr} \text { above Fed rate }\end{array}$ \\
\hline California & $\$ 4.25$ & July 1988 & \\
\hline Connecticut & $\$ 4.25$ & October 1988 & $\$ 3.75$ rate Oct. 1987 \\
\hline Hawaii & $\$ 3.85$ & Jan. 1988 & \\
\hline Minnesota & $\begin{array}{l}\$ 3.85 \\
\$ 3.95\end{array}$ & $\begin{array}{ll}\text { Jan. } & 1989 \\
\text { Jan. } & 1990\end{array}$ & $\begin{array}{l}\text { lower rate for small } \\
\text { firms (exempt from FLSA) }\end{array}$ \\
\hline Rhode Island & $\$ 4.25$ & Aug. 1989 & $\begin{array}{llll}\$ 3.55 & \text { rate July } 1986 \\
\$ 3.65 & \text { rate July } 1987 \\
\$ 4.00 & \text { rate July } 1988\end{array}$ \\
\hline Washington & $\$ 3.85$ & Jan. 1989 & \\
\hline \multicolumn{4}{|l|}{ Others: } \\
\hline D.C. & $\begin{array}{l}\$ 3.50 \\
\text { (retail trade) }\end{array}$ & Sept. 1982 & $\begin{array}{l}\text { rates set by industry/ } \\
\text { occupation. } \$ 3.80 \text { rate } \\
\text { with } \$ 1.95 \text { tip credit } \\
\text { in hotels/food industry }\end{array}$ \\
\hline Maine & $\begin{array}{l}\$ 3.75 \\
\$ 3.85\end{array}$ & $\begin{array}{ll}\text { Jan. } 1989 \\
\text { Jan. } 1990\end{array}$ & $\begin{array}{lll}\$ 3.45 & \text { rate Jan. } & 1985 \\
\$ 3.55 & \text { rate Jan. } & 1986 \\
\$ 3.65 \text { rate Jan. } & 1987\end{array}$ \\
\hline Massachusetts & $\$ 3.75$ & Ju1y 1988 & $\begin{array}{l}\$ 3.55 \text { rate July } 1986 \\
\$ 3.65 \text { rate July } 1987\end{array}$ \\
\hline New Hampshire & $\begin{array}{l}\$ 3.65 \\
\$ 3.75\end{array}$ & $\begin{array}{l}\text { Jan. } 1989 \\
\text { Jan. } 1990\end{array}$ & $\begin{array}{ll}\$ 3.45 \text { rate Jan. } 1987 \\
\$ 3.55 \text { rate Jan. } 1988\end{array}$ \\
\hline North Dakota & $\$ 3.40$ & Aug. 1989 & \\
\hline Oregon & $\$ 3.85$ & Sep. 1989 & \\
\hline Pennsylvania & $\$ 3.70$ & Feb. 1989 & \\
\hline Vermont & $\$ 3.75$ & July 1989 & $\begin{array}{l}\$ 3.45 \text { rate July } 1986 \\
\$ 3.55 \text { rate July } 1987 \\
\$ 3.65 \text { rate July } 1988 \\
\$ 3.65 \text { rate Jan. } 1989\end{array}$ \\
\hline Wisconsin & $\$ 3.65$ & July 1989 & \\
\hline
\end{tabular}




\begin{tabular}{|c|c|c|c|c|c|c|c|c|c|c|c|}
\hline & & \multicolumn{5}{|c|}{ April-December 1989} & \multicolumn{5}{|c|}{ April-December 1990} \\
\hline & & \multirow[b]{3}{*}{ A11 } & \multirow[b]{2}{*}{ Al1 } & \multicolumn{3}{|c|}{ Workers with Wage: } & \multirow[b]{3}{*}{ Al1 } & \multirow[b]{2}{*}{ All } & \multicolumn{3}{|c|}{ Workers with Wage: } \\
\hline & & & & & $\$ 3.35-$ & & & & & $\$ 3.35-$ & \\
\hline & & & Workers & $<\$ 3.35$ & 3.79 & $\geq \$ 3.80$ & & Workers & $<\$ 3.35$ & 3.79 & $\geq \$ 3.80$ \\
\hline 1. & Percent of All & -- & 49.0 & 3.5 & 11.9 & 31.1 & -- & 46.4 & 2.6 & 3.4 & 38.2 \\
\hline 2. & $\begin{array}{c}\text { Percent of } \\
\text { Workers }\end{array}$ & -- & 100.0 & 7.1 & 24.4 & 63.6 & -- & 100.0 & 5.6 & 7.4 & 82.3 \\
\hline 3. & Female $(z)$ & 49.7 & 48.3 & 61.0 & 53.4 & 45.6 & 49.7 & 48.3 & 62.1 & 51.7 & 47.8 \\
\hline 4. & Nonwhite $(\%)$ & 19.0 & 11.9 & 10.7 & 15.1 & 10.8 & 19.7 & 11.8 & 8.3 & 17.5 & 11.4 \\
\hline 5. & Hispanic $(z)$ & 9.9 & 8.1 & 5.5 & 6.9 & 8.8 & 10.4 & 8.7 & 7.9 & 5.9 & 9.2 \\
\hline 6. & Educ $<12(z)$ & 62.8 & 53.0 & 65.2 & 68.1 & 45.8 & 64.4 & 53.1 & 68.6 & 73.4 & 49.9 \\
\hline & Age $16-17(\pi)$ & 48.2 & 38.9 & 52.4 & 54.3 & 31.6 & 48.0 & 37.6 & 50.1 & 54.2 & 35.0 \\
\hline 8. & $\begin{array}{l}\text { Enrolled in } \\
\text { School }\end{array}$ & 56.5 & 45.6 & 51.3 & 55.8 & 41.2 & 57.4 & 46.3 & 48.3 & 61.3 & 45.3 \\
\hline 9 . & Hours/Week & -- & 26.6 & 22.0 & 22.5 & 28.8 & -- & 26.4 & 22.8 & 20.1 & 27.1 \\
\hline 10. & Avg Wage $(\$ / h r)$ & -- & 4.61 & 2.46 & 3.49 & 5.28 & - & 4.84 & 2.46 & 3.54 & 5.12 \\
\hline \multicolumn{12}{|c|}{ Including Tips and Commissions: } \\
\hline & Avg Wage $(\$ / h r)$ & -- & 4.77 & 3.06 & 3.61 & 5.41 & -- & 4.99 & 3.04 & 3.67 & 5.24 \\
\hline 12 . & $\begin{array}{l}\text { Weekly Wage } \\
\text { (\$/week) }\end{array}$ & -- & 134.3 & 69.5 & 82.2 & 161.0 & -- & 137.8 & 70.7 & 79.7 & 147.2 \\
\hline 13. & $\begin{aligned} \text { Percent Reporting } \\
\text { Tips }>0\end{aligned}$ & -- & 11.0 & 24.5 & 12.2 & 9.8 & -- & 11.5 & 28.2 & 13.3 & 10.9 \\
\hline \multicolumn{12}{|c|}{ Industry Distribution: } \\
\hline 14. & Agriculture & -- & 4.2 & 6.0 & 2.2 & 3.4 & -- & 4.4 & 8.9 & 2.5 & 3.3 \\
\hline 15. & Retail Trade & -- & 50.1 & 49.5 & 68.4 & 45.2 & -- & 50.0 & 48.0 & 63.5 & 50.1 \\
\hline 16. & Service & -- & 26.2 & 35.8 & 22.6 & 25.9 & -- & 27.0 & 37.9 & 27.2 & 26.1 \\
\hline 17. & Sample Size & 18511 & 9205 & 674 & 2326 & 5735 & 18549 & 8625 & 499 & 653 & 7049 \\
\hline
\end{tabular}

Notes: Data are taken from 1989 and 1990 monthly Current Population Survey files (outgoing rotation groups for April-December of each year). All workers include unpaid and selfemployed workers. Workers in specified wage ranges exclude self-employed

workers and those with allocated hourly or weekly earnings. Wage measure in row 10 is based on straight-time wages of hourly-rated workers. Wage in row 11 includes pro-rated tips and commissions for hourly-rated workers. 
Table 2 Mean Log Wages and Employment Rates In Three Groups of States

(standard errors in parentheses)

\begin{tabular}{|c|c|c|c|c|c|c|}
\hline \multirow[b]{2}{*}{ Group: } & \multicolumn{3}{|c|}{ Mean Log Wages } & \multicolumn{3}{|c|}{ Employment Rates } \\
\hline & $\begin{array}{l}\text { Low } \\
\text { Wage }\end{array}$ & $\begin{array}{l}\text { Medium } \\
\text { Wage }\end{array}$ & $\begin{array}{l}\text { High } \\
\text { Wage }\end{array}$ & $\begin{array}{l}\text { Low } \\
\text { Wage }\end{array}$ & $\begin{array}{l}\text { Medium } \\
\text { Wage }\end{array}$ & $\begin{array}{l}\text { High } \\
\text { Wage }\end{array}$ \\
\hline \multicolumn{7}{|l|}{ 1989: } \\
\hline$I$ & $\begin{array}{c}1.33 \\
(0.01)\end{array}$ & $\begin{array}{c}1.41 \\
(0.01)\end{array}$ & $\begin{array}{c}1.56 \\
(0.01)\end{array}$ & $\begin{array}{l}33.9 \\
(1.4)\end{array}$ & $\begin{array}{l}44.4 \\
(0.9)\end{array}$ & $\begin{array}{l}44.3 \\
(1.1)\end{array}$ \\
\hline II & $\begin{array}{c}1.33 \\
(0.01)\end{array}$ & $\begin{array}{c}1.42 \\
(0.01)\end{array}$ & $\begin{array}{c}1.58 \\
(0.01)\end{array}$ & $\begin{array}{l}37.9 \\
(1.5)\end{array}$ & $\begin{array}{l}50.8 \\
(0.9)\end{array}$ & $\begin{array}{l}45.4 \\
(1.2)\end{array}$ \\
\hline III & $\begin{array}{c}1.35 \\
(0.01)\end{array}$ & $\begin{array}{c}1.43 \\
(0.01)\end{array}$ & $\begin{array}{c}1.61 \\
(0.01)\end{array}$ & $\begin{array}{l}45.4 \\
(1.5)\end{array}$ & $\begin{array}{l}55.7 \\
(0.9)\end{array}$ & $\begin{array}{l}52.0 \\
(1.1)\end{array}$ \\
\hline IV & $\begin{array}{c}1.37 \\
(0.02)\end{array}$ & $\begin{array}{c}1.44 \\
(0.01)\end{array}$ & $\begin{array}{c}1.58 \\
(0.01)\end{array}$ & $\begin{array}{l}41.7 \\
(1.5)\end{array}$ & $\begin{array}{l}47.5 \\
(0.9)\end{array}$ & $\begin{array}{l}46.6 \\
(1.1)\end{array}$ \\
\hline \multicolumn{7}{|l|}{ 1990: } \\
\hline$I$ & $\begin{array}{c}1.38 \\
(0.02)\end{array}$ & $\begin{array}{c}1.44 \\
(0.01)\end{array}$ & $\begin{array}{c}1.61 \\
(0.01)\end{array}$ & $\begin{array}{l}37.8 \\
(1.5)\end{array}$ & $\begin{array}{l}45.5 \\
(0.9)\end{array}$ & $\begin{array}{l}42.0 \\
(1.1)\end{array}$ \\
\hline II & $\begin{array}{c}1.45 \\
(0.01)\end{array}$ & $\begin{array}{c}1.48 \\
(0.01)\end{array}$ & $\begin{array}{c}1.62 \\
(0.01)\end{array}$ & $\begin{array}{l}44.1 \\
(1.5)\end{array}$ & $\begin{array}{l}50.0 \\
(0.9)\end{array}$ & $\begin{array}{l}45.8 \\
(1.1)\end{array}$ \\
\hline III & $\begin{array}{c}1.43 \\
(0.02)\end{array}$ & $\begin{array}{c}1.48 \\
(0.01)\end{array}$ & $\begin{array}{c}1.66 \\
(0.01)\end{array}$ & $\begin{array}{l}42.6 \\
(1.5)\end{array}$ & $\begin{array}{l}50.8 \\
(0.9)\end{array}$ & $\begin{array}{l}49.0 \\
(1.1)\end{array}$ \\
\hline IV & $\begin{array}{c}1.47 \\
(0.02)\end{array}$ & $\begin{array}{c}1.50 \\
(0.01)\end{array}$ & $\begin{array}{c}1.61 \\
(0.01)\end{array}$ & $\begin{array}{l}34.7 \\
(1.4)\end{array}$ & $\begin{array}{l}45.1 \\
(0.9)\end{array}$ & $\begin{array}{l}41.0 \\
(1.1)\end{array}$ \\
\hline \multicolumn{7}{|c|}{ Change from 1989 to same quarter of 1990: } \\
\hline I & $\begin{array}{c}0.05 \\
(0.02)\end{array}$ & $\begin{array}{c}0.03 \\
(0.01)\end{array}$ & $\begin{array}{c}0.05 \\
(0.02)\end{array}$ & $\begin{array}{c}3.9 \\
(2.0)\end{array}$ & $\begin{array}{l}1.1 \\
(1.3)\end{array}$ & $\begin{array}{l}-2.3 \\
(1.5)\end{array}$ \\
\hline II & $\begin{array}{c}0.12 \\
(0.02)\end{array}$ & $\begin{array}{c}0.06 \\
(0.01)\end{array}$ & $\begin{array}{c}0.04 \\
(0.01)\end{array}$ & $\begin{array}{c}6.2 \\
(2.1)\end{array}$ & $\begin{array}{l}-0.8 \\
(1.3)\end{array}$ & $\begin{array}{c}0.4 \\
(1.6)\end{array}$ \\
\hline III & $\begin{array}{c}0.08 \\
(0.02)\end{array}$ & $\begin{array}{c}0.05 \\
(0.01)\end{array}$ & $\begin{array}{c}0.05 \\
(0.01)\end{array}$ & $\begin{array}{l}-2.8 \\
(2.1)\end{array}$ & $\begin{array}{l}-4.9 \\
(1.3)\end{array}$ & $\begin{array}{l}-3.0 \\
(1.5)\end{array}$ \\
\hline IV & $\begin{array}{c}0.10 \\
(0.02)\end{array}$ & $\begin{array}{c}0.06 \\
(0.01)\end{array}$ & $\begin{array}{c}0.03 \\
(0.02)\end{array}$ & $\begin{array}{l}-7.0 \\
(2.1)\end{array}$ & $\begin{array}{l}-2.4 \\
(1.3)\end{array}$ & $\begin{array}{l}-5.6 \\
(1.5)\end{array}$ \\
\hline $\begin{array}{l}\text { Average for } \\
\text { II, III, IV }\end{array}$ & $\begin{array}{c}0.10 \\
(0.01)\end{array}$ & $\begin{array}{c}0.06 \\
(0.01)\end{array}$ & $\begin{array}{c}0.04 \\
(0.01)\end{array}$ & $\begin{array}{l}-1.2 \\
(1.2)\end{array}$ & $\begin{array}{l}-2.7 \\
(0.8)\end{array}$ & $\begin{array}{l}-2.7 \\
(0.9)\end{array}$ \\
\hline
\end{tabular}

Note: Low wage group includes states with $>40 \%$ of teens earning $\$ 3.35-$ 3.79 per hour in 1989. High wage group includes states with $<20 \%$ of teens earning $\$ 3.35-3.79$ per hour in 1989. Medium wage group includes all other states. 
Table 3 Employment and Wage Data for Teenagers, By State, 1989 and 1990

\begin{tabular}{|c|c|c|c|c|c|c|c|c|c|c|}
\hline & \multirow{2}{*}{$\begin{array}{c}\% \text { Earning } \\
\$ 3.35-3.79 \\
\text { In } 1989\end{array}$} & \multicolumn{2}{|c|}{$\begin{array}{l}\text { Average Wage } \\
\text { in } 1989 \\
\end{array}$} & \multicolumn{2}{|c|}{$\begin{array}{l}\text { Employment Rate } \\
\text { in } 1989 \\
\end{array}$} & \multicolumn{2}{|c|}{$\begin{array}{l}\text { Chg in Mean Log } \\
\text { Wage } 1989-90\end{array}$} & \multicolumn{2}{|c|}{$\begin{array}{c}\text { Chg in Employment } \\
\text { Rate } 1989-90 \\
\end{array}$} & \multirow{2}{*}{$\begin{array}{c}\text { Average } \\
\text { Sample } \\
\text { Size }\end{array}$} \\
\hline & & Mean & Std Err & Mean & Std Err & Change & $\overline{\text { std Err }}$ & Change & Std Err & \\
\hline \multicolumn{11}{|l|}{ New England } \\
\hline $\begin{array}{l}\text { Maine } \\
\text { New Hampshire } \\
\text { Vermont } \\
\text { Massachusetts } \\
\text { Rhode Is land } \\
\text { Connect icut }\end{array}$ & $\begin{array}{r}9.4 \\
3.9 \\
14.3 \\
4.0 \\
4.9 \\
1.3\end{array}$ & $\begin{array}{l}5.10 \\
5.35 \\
4.52 \\
5.47 \\
5.17 \\
5.70\end{array}$ & $\begin{array}{l}0.21 \\
0.19 \\
0.14 \\
0.08 \\
0.12 \\
0.19\end{array}$ & $\begin{array}{l}53.3 \\
50.1 \\
54.5 \\
53.3 \\
62.0 \\
45.4\end{array}$ & $\begin{array}{l}3.4 \\
3.9 \\
4.2 \\
1.9 \\
3.7 \\
3.9\end{array}$ & $\begin{array}{r}2.53 \\
-2.39 \\
8.07 \\
4.81 \\
7.00 \\
1.62\end{array}$ & $\begin{array}{l}4.14 \\
4.58 \\
3.80 \\
2.21 \\
3.19 \\
4.72\end{array}$ & $\begin{array}{r}0.4 \\
6.9 \\
-4.6 \\
-3.2 \\
-2.1 \\
7.0\end{array}$ & $\begin{array}{l}4.6 \\
5.3 \\
5.7 \\
2.6 \\
5.1 \\
5.3\end{array}$ & $\begin{array}{l}214 \\
157 \\
138 \\
680 \\
163 \\
158\end{array}$ \\
\hline \multicolumn{11}{|l|}{ Middle At lant ic } \\
\hline $\begin{array}{l}\text { New York } \\
\text { New Jersey } \\
\text { Pennsylvania }\end{array}$ & $\begin{array}{r}17.7 \\
9.3 \\
23.8\end{array}$ & $\begin{array}{l}5.03 \\
5.52 \\
4.68\end{array}$ & $\begin{array}{l}0.09 \\
0.10 \\
0.09\end{array}$ & $\begin{array}{l}42.2 \\
42.0 \\
49.5\end{array}$ & $\begin{array}{l}1.5 \\
1.8 \\
1.9\end{array}$ & $\begin{array}{l}2.01 \\
5.43 \\
3.41\end{array}$ & $\begin{array}{l}2.12 \\
2.50 \\
2.29\end{array}$ & $\begin{array}{r}-3.2 \\
0.4 \\
-1.1\end{array}$ & $\begin{array}{l}1.9 \\
2.5 \\
2.5\end{array}$ & $\begin{array}{r}1188 \\
704 \\
733\end{array}$ \\
\hline \multicolumn{11}{|c|}{ East North Central } \\
\hline $\begin{array}{l}\text { Ohio } \\
\text { Indiana } \\
\text { Illinois } \\
\text { Michigan } \\
\text { Wisconsin }\end{array}$ & $\begin{array}{l}31.8 \\
26.5 \\
29.2 \\
32.3 \\
32.9\end{array}$ & $\begin{array}{l}4.41 \\
4.47 \\
4.50 \\
4.49 \\
4.19\end{array}$ & $\begin{array}{l}0.08 \\
0.13 \\
0.08 \\
0.08 \\
0.12\end{array}$ & $\begin{array}{l}53.1 \\
61.5 \\
52.6 \\
53.4 \\
57.4\end{array}$ & $\begin{array}{l}1.6 \\
3.1 \\
1.7 \\
1.7 \\
3.0\end{array}$ & $\begin{array}{l}4.20 \\
1.81 \\
5.28 \\
4.03 \\
6.96\end{array}$ & $\begin{array}{l}1.96 \\
3.49 \\
2.11 \\
2.05 \\
3.64\end{array}$ & $\begin{array}{r}-1.7 \\
-8.3 \\
-6.1 \\
-3.4 \\
6.9\end{array}$ & $\begin{array}{l}2.2 \\
4.3 \\
2.4 \\
2.3 \\
4.1\end{array}$ & $\begin{array}{l}892 \\
235 \\
806 \\
886 \\
256\end{array}$ \\
\hline \multicolumn{11}{|c|}{ West North Central } \\
\hline $\begin{array}{l}\text { Minnesota } \\
\text { lowa } \\
\text { Missouri } \\
\text { North Dakota } \\
\text { South Dakota } \\
\text { Nebraska } \\
\text { Kansas }\end{array}$ & $\begin{array}{l}15.4 \\
34.7 \\
38.2 \\
43.8 \\
49.8 \\
35.1 \\
33.3\end{array}$ & $\begin{array}{l}4.65 \\
3.96 \\
4.06 \\
3.96 \\
3.72 \\
3.95 \\
4.17\end{array}$ & $\begin{array}{l}0.15 \\
0.08 \\
0.16 \\
0.10 \\
0.09 \\
0.11 \\
0.13\end{array}$ & $\begin{array}{l}65.1 \\
58.5 \\
52.7 \\
56.3 \\
59.6 \\
59.0 \\
60.3\end{array}$ & $\begin{array}{l}3.3 \\
3.3 \\
3.4 \\
3.1 \\
2.9 \\
3.2 \\
3.3\end{array}$ & $\begin{array}{r}3.92 \\
4.72 \\
7.00 \\
5.66 \\
15.51 \\
11.24 \\
9.03\end{array}$ & $\begin{array}{l}3.39 \\
3.09 \\
3.83 \\
3.25 \\
2.94 \\
3.72 \\
3.76\end{array}$ & $\begin{array}{r}-4.1 \\
1.9 \\
3.3 \\
1.4 \\
-1.5 \\
2.7 \\
-0.5\end{array}$ & $\begin{array}{l}4.4 \\
4.5 \\
4.5 \\
4.1 \\
3.9 \\
4.5 \\
4.3\end{array}$ & $\begin{array}{l}212 \\
216 \\
222 \\
260 \\
282 \\
218 \\
231\end{array}$ \\
\hline \multicolumn{11}{|l|}{ South Atlantic } \\
\hline $\begin{array}{l}\text { Delaware } \\
\text { Maryland } \\
\text { D.C. } \\
\text { Virginia } \\
\text { West Virginia } \\
\text { North Carol ina } \\
\text { South Carol ina } \\
\text { Georgia } \\
\text { Florida }\end{array}$ & $\begin{array}{l}12.3 \\
17.1 \\
14.9 \\
20.5 \\
54.4 \\
30.7 \\
40.9 \\
31.4 \\
24.5\end{array}$ & $\begin{array}{l}5.18 \\
4.86 \\
5.15 \\
4.81 \\
3.79 \\
4.39 \\
4.32 \\
4.56 \\
4.70\end{array}$ & $\begin{array}{l}0.16 \\
0.19 \\
0.22 \\
0.15 \\
0.17 \\
0.07 \\
0.15 \\
0.18 \\
0.09\end{array}$ & $\begin{array}{l}62.0 \\
50.5 \\
38.0 \\
49.7 \\
33.8 \\
53.3 \\
44.8 \\
46.4 \\
47.2\end{array}$ & $\begin{array}{l}3.8 \\
3.7 \\
4.4 \\
3.0 \\
2.9 \\
1.7 \\
2.9 \\
3.3 \\
1.8\end{array}$ & $\begin{array}{r}1.36 \\
9.19 \\
6.70 \\
4.34 \\
13.14 \\
7.83 \\
4.32 \\
14.40 \\
2.66\end{array}$ & $\begin{array}{l}4.38 \\
5.17 \\
5.41 \\
3.83 \\
4.88 \\
1.95 \\
3.72 \\
4.56 \\
2.09\end{array}$ & $\begin{array}{r}-5.6 \\
-6.9 \\
2.6 \\
-6.9 \\
-3.7 \\
-7.8 \\
-8.4 \\
0.4 \\
-3.0\end{array}$ & $\begin{array}{l}5.2 \\
5.0 \\
5.8 \\
4.0 \\
3.8 \\
2.4 \\
3.9 \\
4.7 \\
2.4\end{array}$ & $\begin{array}{l}159 \\
177 \\
128 \\
281 \\
273 \\
808 \\
285 \\
208 \\
784\end{array}$ \\
\hline \multicolumn{11}{|c|}{ East South Central } \\
\hline $\begin{array}{l}\text { Kentucky } \\
\text { Tennessee } \\
\text { Alabama } \\
\text { Mississippi }\end{array}$ & $\begin{array}{l}49.9 \\
49.9 \\
30.4 \\
51.3\end{array}$ & $\begin{array}{l}3.91 \\
4.06 \\
4.39 \\
3.95\end{array}$ & $\begin{array}{l}0.11 \\
0.14 \\
0.13 \\
0.10\end{array}$ & $\begin{array}{l}46.2 \\
43.8 \\
42.5 \\
32.7\end{array}$ & $\begin{array}{l}3.4 \\
3.2 \\
3.2 \\
2.8\end{array}$ & $\begin{array}{r}6.49 \\
14.40 \\
-2.82 \\
6.66\end{array}$ & $\begin{array}{l}3.79 \\
3.89 \\
3.82 \\
3.46\end{array}$ & $\begin{array}{r}-0.5 \\
0.6 \\
-5.5 \\
-1.3\end{array}$ & $\begin{array}{l}4.5 \\
4.2 \\
4.3 \\
3.6\end{array}$ & $\begin{array}{l}219 \\
254 \\
231 \\
297\end{array}$ \\
\hline \multicolumn{11}{|c|}{ West South Central } \\
\hline $\begin{array}{l}\text { Arkansas } \\
\text { Louisiana } \\
\text { Oklahoma } \\
\text { Texas }\end{array}$ & $\begin{array}{l}51.7 \\
45.6 \\
41.2 \\
37.6\end{array}$ & $\begin{array}{l}3.94 \\
3.93 \\
4.23 \\
4.19\end{array}$ & $\begin{array}{l}0.11 \\
0.12 \\
0.18 \\
0.08\end{array}$ & $\begin{array}{l}41.0 \\
35.4 \\
43.1 \\
44.0\end{array}$ & $\begin{array}{l}3.0 \\
3.1 \\
3.1 \\
1.6\end{array}$ & $\begin{array}{r}8.59 \\
11.60 \\
9.83 \\
6.41\end{array}$ & $\begin{array}{l}3.28 \\
4.33 \\
4.19 \\
2.02\end{array}$ & $\begin{array}{r}6.5 \\
-6.8 \\
4.4 \\
-4.2\end{array}$ & $\begin{array}{l}4.2 \\
4.1 \\
4.3 \\
2.2\end{array}$ & $\begin{array}{l}250 \\
229 \\
246 \\
943\end{array}$ \\
\hline \multicolumn{11}{|l|}{ Mountain } \\
\hline $\begin{array}{l}\text { Montana } \\
\text { Idaho } \\
\text { Wyoming } \\
\text { Colorado } \\
\text { New Mexico } \\
\text { Arizona } \\
\text { Utah } \\
\text { Nevada }\end{array}$ & $\begin{array}{l}54.0 \\
29.0 \\
44.4 \\
34.0 \\
47.4 \\
38.5 \\
38.4 \\
13.2\end{array}$ & $\begin{array}{l}3.79 \\
3.94 \\
3.85 \\
4.16 \\
4.10 \\
4.11 \\
4.38 \\
5.20\end{array}$ & $\begin{array}{l}0.10 \\
0.11 \\
0.14 \\
0.09 \\
0.11 \\
0.11 \\
0.11 \\
0.21\end{array}$ & $\begin{array}{l}52.0 \\
57.6 \\
51.7 \\
58.6 \\
41.0 \\
50.1 \\
63.2 \\
52.7\end{array}$ & $\begin{array}{l}3.4 \\
3.1 \\
3.5 \\
3.6 \\
3.1 \\
3.7 \\
2.8 \\
3.5\end{array}$ & $\begin{array}{l}10.29 \\
15.36 \\
13.02 \\
7.21 \\
7.53 \\
9.68 \\
7.75 \\
7.84\end{array}$ & $\begin{array}{l}3.78 \\
3.75 \\
4.09 \\
3.62 \\
3.92 \\
3.61 \\
3.01 \\
3.81\end{array}$ & $\begin{array}{r}-0.7 \\
-2.4 \\
-3.3 \\
-0.9 \\
2.6 \\
1.3 \\
-2.5 \\
-1.0\end{array}$ & $\begin{array}{l}4.4 \\
4.0 \\
4.8 \\
4.9 \\
4.3 \\
4.8 \\
3.8 \\
4.8\end{array}$ & $\begin{array}{l}228 \\
273 \\
196 \\
183 \\
243 \\
198 \\
288 \\
194\end{array}$ \\
\hline \multicolumn{11}{|l|}{ Pacific } \\
\hline $\begin{array}{l}\text { Hashington } \\
\text { Oregon } \\
\text { Cal ifornia } \\
\text { Alaska } \\
\text { Hawai i }\end{array}$ & $\begin{array}{r}8.2 \\
27.6 \\
3.2 \\
0.0 \\
1.3\end{array}$ & $\begin{array}{l}4.79 \\
4.46 \\
5.29 \\
6.48 \\
5.48\end{array}$ & $\begin{array}{l}0.18 \\
0.14 \\
0.09 \\
0.23 \\
0.29\end{array}$ & $\begin{array}{l}55.5 \\
53.2 \\
47.4 \\
44.4 \\
42.0\end{array}$ & $\begin{array}{l}3.5 \\
3.7 \\
1.5 \\
2.9 \\
3.8\end{array}$ & $\begin{array}{r}15.60 \\
8.27 \\
0.52 \\
-4.79 \\
12.32\end{array}$ & $\begin{array}{l}3.64 \\
4.05 \\
1.72 \\
3.56 \\
6.71\end{array}$ & $\begin{array}{r}6.3 \\
-1.7 \\
-5.6 \\
2.5 \\
-1.1\end{array}$ & $\begin{array}{l}4.7 \\
4.9 \\
1.9 \\
4.0 \\
5.2\end{array}$ & $\begin{array}{r}196 \\
184 \\
1298 \\
280 \\
159\end{array}$ \\
\hline All U.S. & 25.7 & 4.61 & 0.02 & 49.0 & 0.4 & 5.45 & 0.46 & -2.6 & 0.5 & 18530 \\
\hline
\end{tabular}

Note: Based on sample averages from the 1989 and 1990 Current Population Surveys, April to December only. 
Table 4 Estimated Regression Equations for State-Average Changes in Wages and Employment Rates of Teenagers, 1989-1990

(estimated standard errors in parentheses)

\begin{tabular}{|c|c|c|c|c|c|c|c|c|c|}
\hline & \multicolumn{3}{|c|}{$\begin{array}{l}\text { Equations for Change } \\
\text { in Mean Log Wage: }\end{array}$} & \multicolumn{6}{|c|}{$\begin{array}{l}\text { Equations for Change in Teen } \\
\text { Employment-Population Rate: }\end{array}$} \\
\hline & (1) & (2) & (3) & (4) & (5) & (6) & $(7)$ & (8) & (9) \\
\hline $\begin{array}{l}\text { 1. Fraction of } \\
\text { Affected Teens }\end{array}$ & $\begin{array}{c}0.15 \\
(0.03)\end{array}$ & $\begin{array}{c}0.14 \\
(0.04)\end{array}$ & $\begin{array}{c}0.15 \\
(0.04)\end{array}$ & $\begin{array}{l}0.02 \\
(0.03)\end{array}$ & $\begin{array}{l}-0.01 \\
(0.03)\end{array}$ & $\begin{array}{l}0.01 \\
(0.04)\end{array}$ & -- & -- & -- \\
\hline $\begin{array}{l}\text { 2. Change in Overall } \\
\text { Emp/Pop Rate }\end{array}$ & -- & $\begin{array}{c}0.46 \\
(0.60)\end{array}$ & -- & - & $\begin{array}{c}1.24 \\
(0.60)\end{array}$ & -- & - & $\begin{array}{c}1.27 \\
(0.66)\end{array}$ & -- \\
\hline $\begin{array}{l}\text { 3. Change in Overall } \\
\text { Unemployment Rate }\end{array}$ & -- & - & $\begin{array}{l}-0.24 \\
(0.92)\end{array}$ & -- & -- & $\begin{array}{l}-0.16 \\
(0.95)\end{array}$ & -- & -- & $\begin{array}{l}-0.13 \\
(0.98)\end{array}$ \\
\hline $\begin{array}{l}\text { 4. Change in Mean Log } \\
\text { Teenage Wage }\end{array}$ & -- & -- & -- & -- & -- & -- & $\begin{array}{c}0.12 \\
(0.22)\end{array}$ & $\begin{array}{l}-0.06 \\
(0.24)\end{array}$ & $\begin{array}{l}0.10 \\
(0.30)\end{array}$ \\
\hline 5. R-squared & 0.30 & 0.31 & 0.30 & 0.01 & 0.09 & 0.01 & 0.01 & 0.09 & 0.01 \\
\hline
\end{tabular}

Notes: Estimated on sample of 51 state observations. Regressions are weighted by average CPS extract sizes for teenage workers in each state. All regressions include an unrestricted constant. Mean and standard deviation of dependent variable in columns 1-3 are 0.0571 and 0.0417 . Mean and standard deviation of dependent variable in columns 4-9 are -0.0225 and 0.0361 .

In workers earning $\$ 3.35-3.79$ in 1989 . 
Table 5 Estimated Regression Equations for State-Average Changes in Employment Rate of Teenagers, $1989-1990$

(estimated standard errors in parentheses)

\begin{tabular}{|c|c|c|c|c|c|c|c|c|c|}
\hline & \multicolumn{4}{|c|}{$\begin{array}{l}\text { Reduced Form } \\
\text { Employment Equations }\end{array}$} & \multicolumn{5}{|c|}{$\begin{array}{c}\text { Structural Employment } \\
\text { Demand Equations }\end{array}$} \\
\hline & \multirow{2}{*}{$\begin{array}{l}\text { OLS } \\
(1)\end{array}$} & \multirow{2}{*}{$\begin{array}{l}\text { OLS } \\
(2)\end{array}$} & \multirow{2}{*}{$\begin{array}{l}I V^{a} \\
(3)\end{array}$} & \multirow{2}{*}{$\begin{array}{l}\text { OLS } \\
(4)\end{array}$} & \multirow[b]{2}{*}{ (5) } & \multicolumn{3}{|c|}{ Instrumental Variables } & \multirow[b]{2}{*}{ (9) } \\
\hline & & & & & & (6) & (7) & (8) & \\
\hline $\begin{array}{l}\text { 1. Fraction of } \\
\text { Affected Teens }\end{array}$ & $\begin{array}{c}0.02 \\
(0.04)\end{array}$ & $\begin{array}{c}0.02 \\
(0.04)\end{array}$ & $\begin{array}{c}0.02 \\
(0.06)\end{array}$ & $\begin{array}{l}-0.00 \\
(0.04)\end{array}$ & -- & -- & -- & -- & -- \\
\hline $\begin{array}{l}\text { 2. Change in Overall } \\
\text { Emp/Pop Rate }\end{array}$ & $\begin{array}{l}1.05 \\
(0.58)\end{array}$ & $\begin{array}{c}1.05 \\
(0.59)\end{array}$ & $\begin{array}{c}1.04 \\
(0.65)\end{array}$ & $\begin{array}{c}0.81 \\
(0.62)\end{array}$ & $\begin{array}{c}0.95 \\
(0.65)\end{array}$ & $\begin{array}{c}0.82 \\
(0.67)\end{array}$ & $\begin{array}{c}0.92 \\
(0.64)\end{array}$ & $\begin{array}{c}0.94 \\
(0.64)\end{array}$ & $\begin{array}{l}1.10 \\
(0.62)\end{array}$ \\
\hline $\begin{array}{l}\text { 3. Lagged Change in } \\
\text { Teen Emp/Pop } \\
\text { Rate }\end{array}$ & $\begin{array}{l}-0.41 \\
(0.18)\end{array}$ & $\begin{array}{l}-0.41 \\
(0.20)\end{array}$ & $\begin{array}{l}-0.44 \\
(0.63)\end{array}$ & $\begin{array}{l}-0.44 \\
(0.19)\end{array}$ & $\begin{array}{l}-0.44 \\
(0.20)\end{array}$ & $\begin{array}{l}-0.44 \\
(0.21)\end{array}$ & $\begin{array}{l}-0.45 \\
(0.20)\end{array}$ & $\begin{array}{l}-0.45 \\
(0.20)\end{array}$ & $\begin{array}{l}-0.40 \\
(0.20)\end{array}$ \\
\hline $\begin{array}{l}\text { 4. Lagged Change in } \\
\text { Overall Emp/Pop } \\
\text { Rate }\end{array}$ & -- & $\begin{array}{l}-0.03 \\
(0.64)\end{array}$ & -- & - & -- & -- & - & -- & -- \\
\hline $\begin{array}{c}\text { 5. Change in Regional } \\
\text { Emp/Pop Rate }\end{array}$ & -- & -- & -- & $\begin{array}{c}1.61 \\
(1.49)\end{array}$ & -- & $\begin{array}{c}1.63 \\
(1.60)\end{array}$ & -- & -- & -- \\
\hline $\begin{array}{c}\text { 6. Change in Mean Log } \\
\text { Teenage Wage }\end{array}$ & -- & -- & -- & -- & $\begin{array}{c}0.16 \\
(0.28)\end{array}$ & $\begin{array}{l}-0.02 \\
(0.36)\end{array}$ & $\begin{array}{c}0.19 \\
(0.27)\end{array}$ & $\begin{array}{c}0.18 \\
(0.27)\end{array}$ & $\begin{array}{c}0.06 \\
(0.23)\end{array}$ \\
\hline 7. R-squared & 0.18 & 0.18 & 0.11 & 0.20 & 0.18 & 0.19 & 0.18 & 0.18 & 0.17 \\
\hline
\end{tabular}

Notes: See note to Table 4. In all columns the dependent variable is the change in the stateaverage teenage employment rate from 1989 to 1990 (April-December Only).

an column 3 the lagged change in the teenage employment-population ratio is instrumented by the lagged change in the overall employment-population ratio.

Change in mean log teenage wage is endogenous. In columns 5 and 6 instument is fraction of teenagers in state earning \$3.35-3.79 per hour in 1989. In column 7 instrument is fraction earning $\$ 3.35$ per hour in 1989. In column 8 instruments are fractions earning exactly $\$ 3.35$ and $\$ 3.35-3.79$ per hour in 1989. In column 9 instruments are fractions earning less than $\$ 3.35$ per hour and $\$ 3.35-3.79$ per hour in 1989 . 
Figure 1

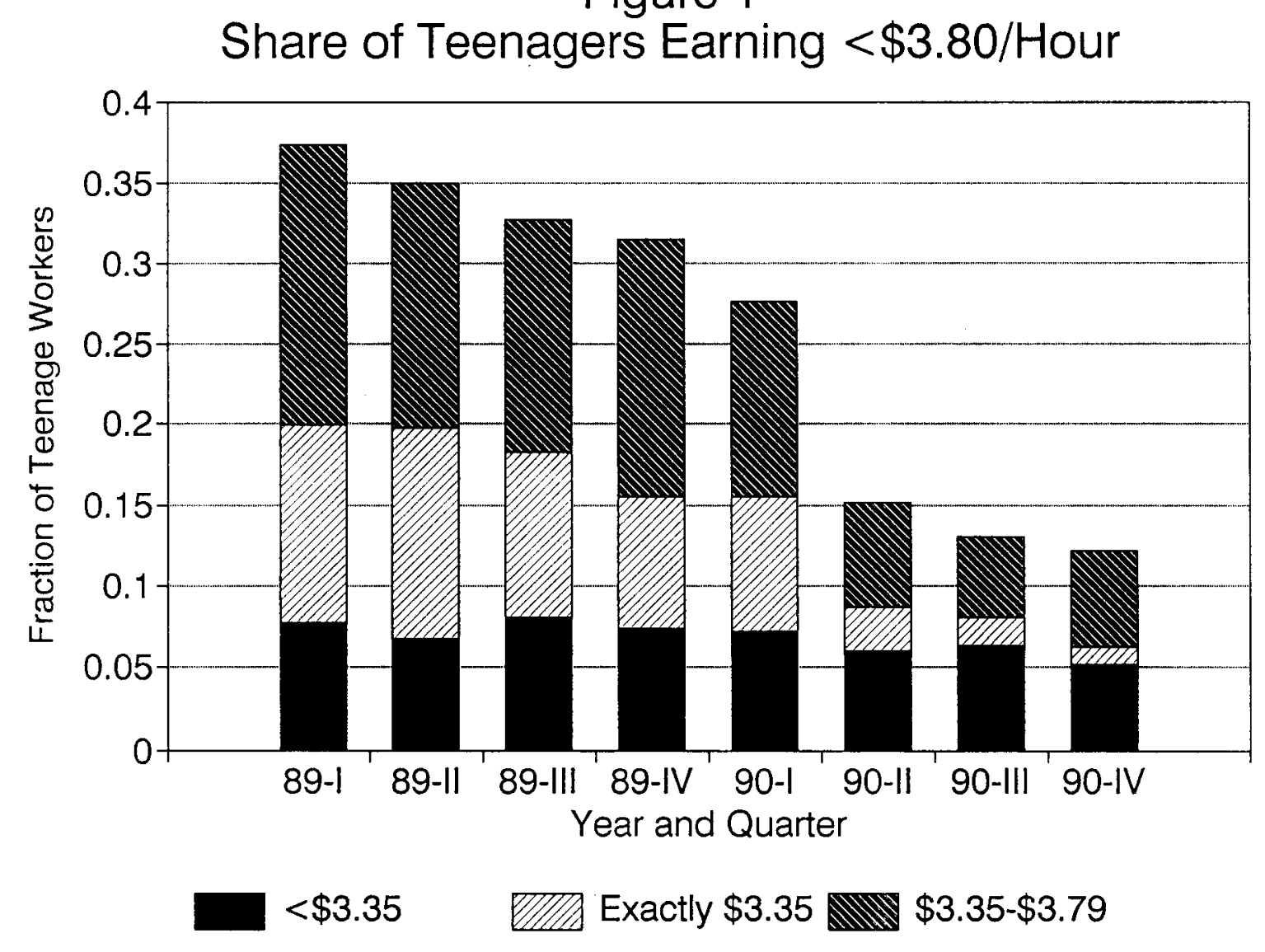


Figure 2

Teenage Employment-Population Rate Actual and Predicted

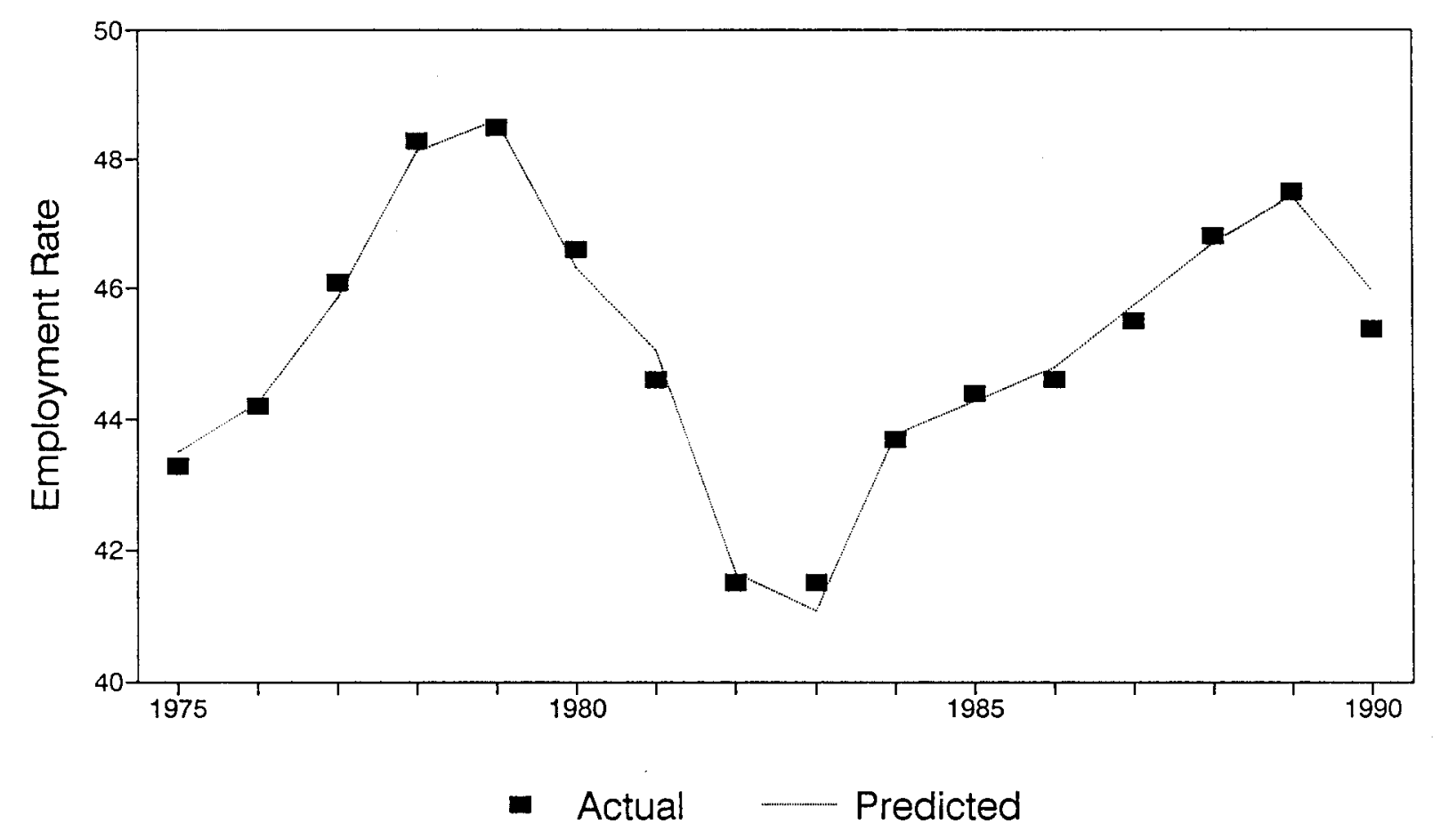


Figure 3

Fractions Earning \$3.35-3.79/Hour

Teenage Workers in 3 Groups of States

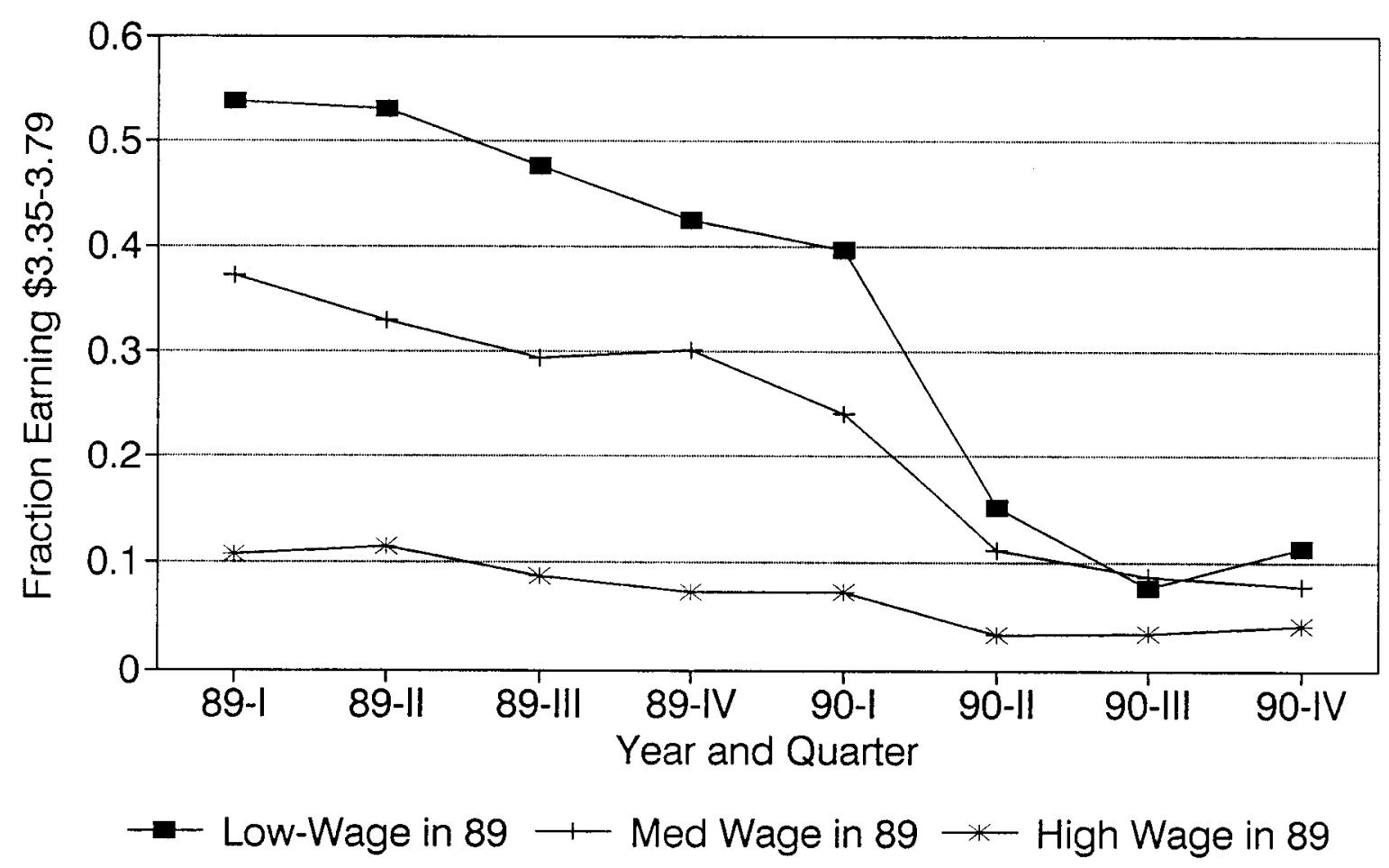


Figure 4

Change in Mean Log Wage of Teen Workers

Vs Percent Earning \$3.35-\$3.79 in 1989

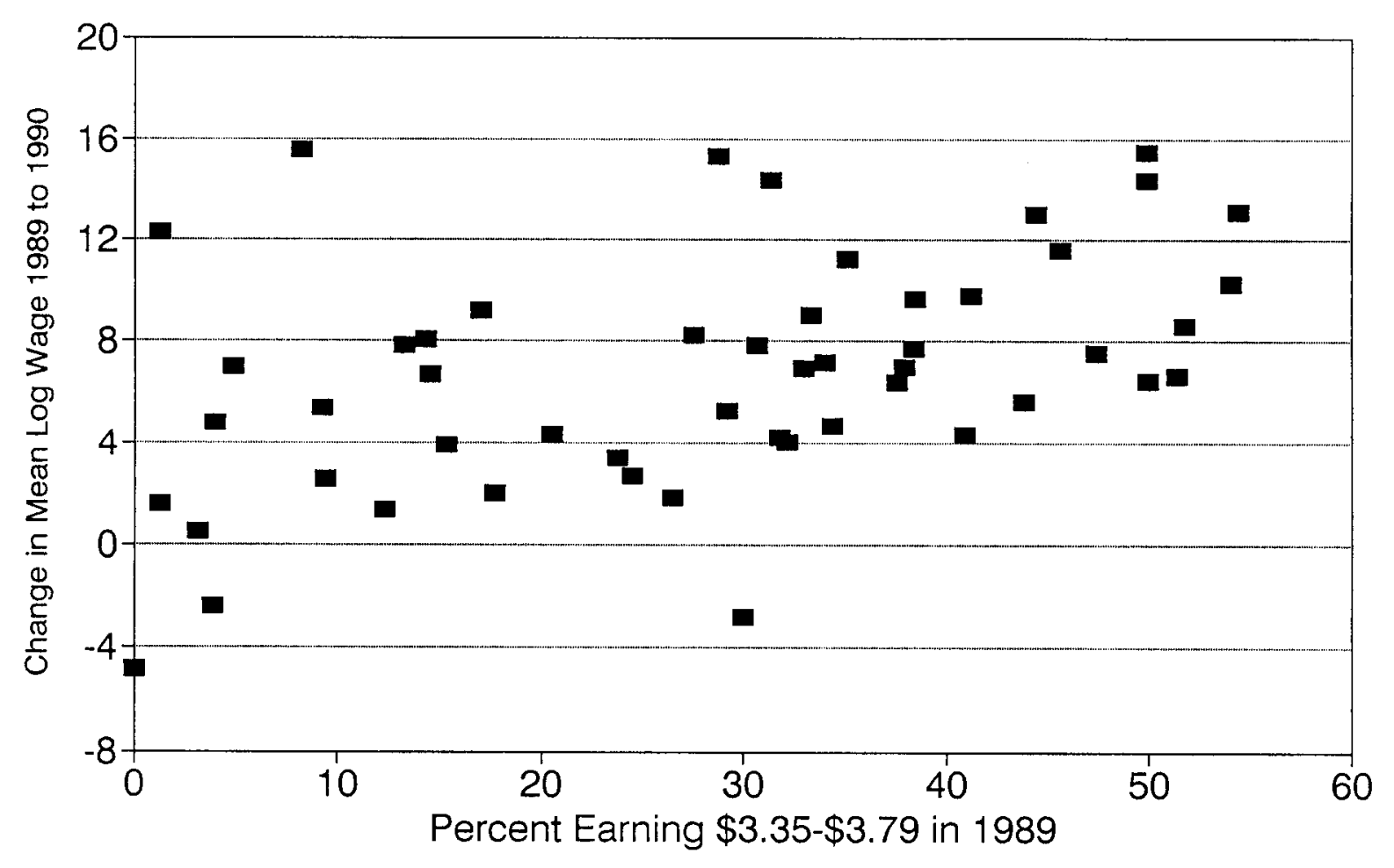


Figure 5

Change in Teenage Employment Rates

Vs Percent Earning \$3.35-\$3.79 in 1989

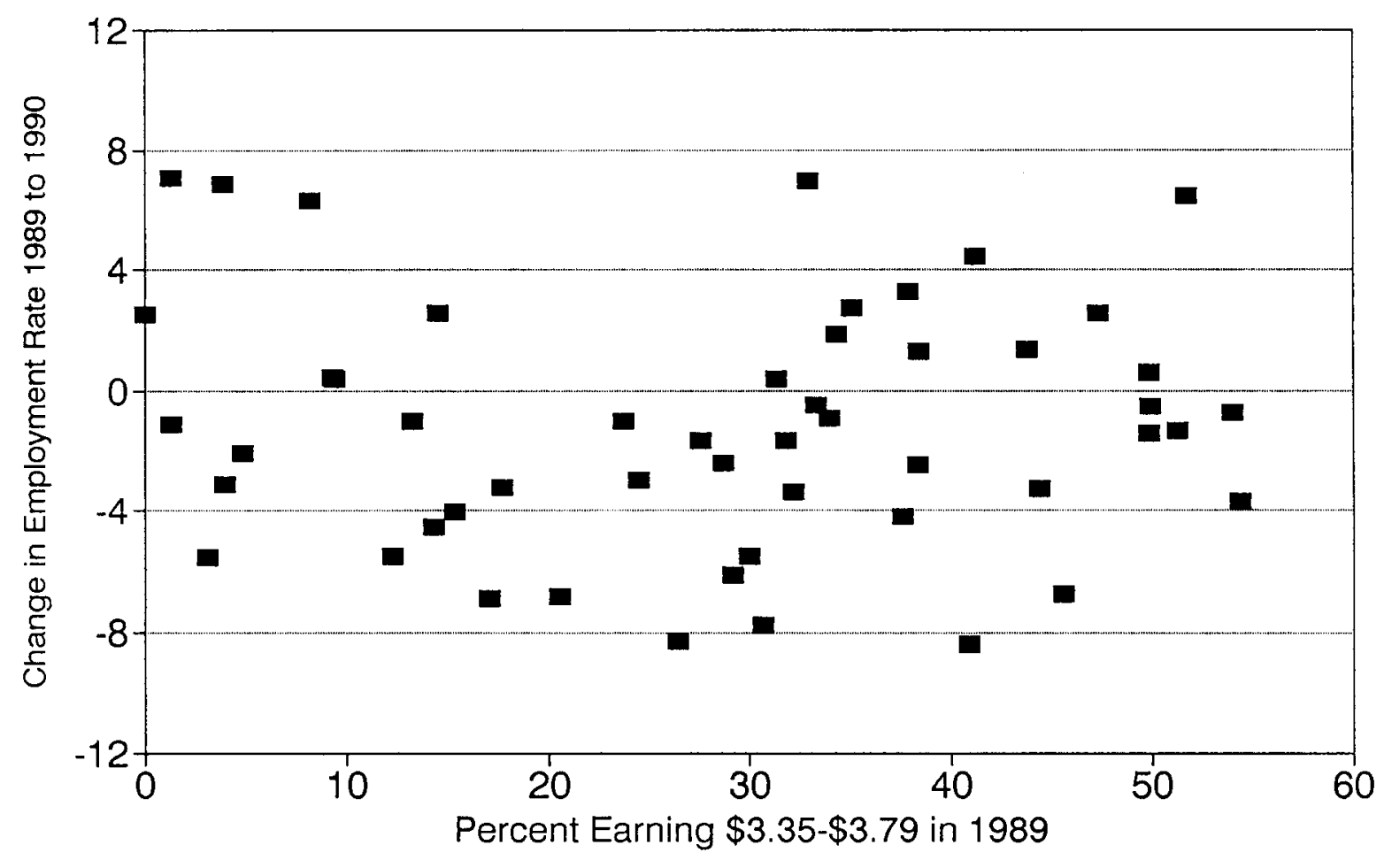

